\title{
The Match of Teaching and Learning Styles in SLA
}

\author{
Jiafeng Liu',2, Qingshun He ${ }^{1}$ \\ ${ }^{1}$ Guangdong University of Foreign Studies, Guangzhou, China \\ ${ }^{2}$ Southwest University for Nationalities, Chengdu, China \\ Email: Janet27@21cn.com
}

Received 31 March 2014; revised 30 April 2014; accepted 13 May 2014

Copyright (C) 2014 by authors and Scientific Research Publishing Inc.

This work is licensed under the Creative Commons Attribution International License (CC BY). http://creativecommons.org/licenses/by/4.0/

(c) (i) 0 pen Access

\begin{abstract}
The match of teaching and learning styles plays an important part in the research of second language acquisition in tertiary education. This paper analyzes the connotation and the research perspectives of the match of teaching and learning styles in tertiary learners' second language acquisition, introduces a new measuring indicator: a compatible teaching style, and proposes its achieving methods: 1) initiating a student-centered teaching style, 2) developing a proper learning style, and 3 ) adjusting the match of teaching and learning styles.
\end{abstract}

\section{Keywords}

Teaching Style, Learning Style, Match, Measuring Indicator, Achieving Methods

\section{Introduction}

To implement the notion of people-oriented education and individualized teaching, and to transfer the focus of education from teaching to learning, people have begun to study the individual differences in and the influence of the initiative and creativity on foreign language learning. The match of teaching and learning styles in tertiary learners' second language acquisition has become an important part in the research of the match of teaching and learning. In the field of intellectual styles, the argument for the effectiveness of matching teaching styles to students' learning styles has long been prevalent among scholars (Saracho, 1990; Wentura, 1985). Research shows that the match of teaching and learning styles in tertiary learners' second language acquisition can effectively improve students' achievement (Arthurs, 2007; Beck, 2001; Felder \& Brent, 2005; Ford \& Chen, 2001; Rogers, 2009; Shaugnessy, 1998) and exert positive influence on their motivation of and attitudes toward study (Bell, 2007; Tulbure, 2011; Zhang, 2006; Beck, 2001; Marshall, 1991). The mismatch of teaching and learning styles will potentially damage students' interest in and attitude toward learning, hence resulting in poor achievement 
(Felder, 1988; Reid, 1996). However, the mismatch may also have a positive influence (Baker \& Cooke, 1988; Kowoser \& Berman, 1996), and the match does not necessarily affect students' performance (Akdemir \& Koszalka, 2008; Massa \& Mayer, 2006). It can be seen clearly that controversies still exist. The lack of a conceptual framework for both learning style theory and measurement is a common and central criticism in this area (Gardner, 1999; Frank, Eleanora, \& Melody, 2009). After a systematical examination of existing learning style models and instruments, Coffield (2004) identified several inconsistencies in learning style models and instruments and cautioned educators with regards to their use. But, what is the reason for these controversial results? What is the ideal match of teaching and learning styles in tertiary learners' second language acquisition? And how can such an ideal match be achieved?

In this paper, we will explore the reasons for the controversial results from the connotation and the research perspectives, propose a new measuring indicator, and finally put forward the achieving methods of an ideal match of teaching and learning styles for tertiary learners in their second language acquisition.

\section{Connotation}

The concept of learning style refers to the individual differences in approaches to learning based on an individual's preference for using a combination from the dialectic modes (Kolb \& Kolb, 2005). That is, learning styles are the approaches that individuals are generally close to use and improve with which they feel better themselves, in the process of learning, while they transform facts and events into experience by internalization. Teaching styles often reflect teachers' views on teaching and learning and their preferred behaviors. The match of teaching and learning styles means that the teachers' teaching styles are in consistency with the students' learning styles, which will promote the learning and educational effectiveness. "If the two types of styles are in consistency, it's obvious that the teacher's teaching styles match with the students' learning style, otherwise, they mismatch or unmatch.” (Lu, 2009). However, because of the fact that there are different definitions for teaching and learning styles and the classification is rather complicated, different researchers have developed different measuring indicators for different purposes. This enables people to highlight only one or several factors relevant to the match of teaching and learning styles. It is difficult to integrate different researches to conduct a crosswise empirical research. On one hand, different researchers emphasize different measuring methods. This will result in controversial influences of the existing match of teaching and learning styles on the motivation, attitude, presence and achievement in tertiary learners' second language learning. On the other hand, the existing match of teaching and learning styles focuses only on the consistency of the style of teaching and that of learning, ignoring the dominancy of the teachers' self-judging and the changeability of the styles. In other words, the variability and complexity of the teaching and learning styles are ignored. This makes a unidirectional and static rather than a dynamic match of teaching and learning in tertiary learners' second language learning. Therefore, the influence of the match of teaching and learning styles on the teachers and the students cannot be properly measured and a scientific match cannot be acquired.

\section{Research Perspectives}

\subsection{Teacher-Centered}

The traditional second language acquisition research in tertiary education focuses on the teacher-centered match of teaching and learning styles. As there is some evidence that teaching styles can help to interpret the influences of teachers on student achievement and on attitudes towards subjects, teaching styles have received a considerable degree of attention within the educational literature over the past two decades (Aitkin \& Zuzovsky, 1994; Ebenezer \& Zoller, 1993). A considerable number of researches emphasize the importance of beliefs, thoughts, judgments, knowledge, attitudes and theories of teachers for teaching practice (Fullan, 1982; Shuell, 1996; Maxwell, 2001). However, the teacher-centered match emphasizes a unidirectional relationship construction and the students' individual differences are neglected. This is in contradiction with the principle of language acquisition and cannot encourage students to be active in class. The teacher is teaching the students, and the students are passively receiving knowledge, or are mechanically drilling under the teacher's control. They cannot effectively understand their own learning styles or improve their learning abilities based on their learning styles. They are not satisfied with the classroom teaching or enthusiastic for the classroom learning. The research of the teachercentered match focuses on the teaching style, with the students' initiative and creativity ignored. 


\subsection{Student-Centered}

Over the past few decades, there has been a prominent shift in focus from teaching to learning within the field of second language education (Peng, 2002). As a considerable number of studies have shown that students' individual differences play an important role in second language learning (Galbraith \& Gardner, 1988; Oxford \& Ehrman, 1993; Skehan, 1989), especially language learning styles appear to be one of the most important variables influencing performance in a second language (Oxford, 1989), a student-centered match of teaching and learning styles began to be dominant in tertiary learners' SLA. There appears a series of researches on learners' individual differences such as learning strategies, learning aptitude, age, gender, culture and affective domain, especially on the learners' learning styles, according to which the quality of teaching should not be measured by teaching but by learning. Therefore, the second language acquisition research should focus on the language learners. In teaching practice, the student-centered principle is highly treasured. However, in the process of shifting from teaching to learning, extreme ideas occurred. Some teachers changed their teaching styles to meet the students' requirement only to lose themselves. This to some extent is a neglect of the teacher's leading role, and the desired objective of teaching is difficult to be achieved.

\subsection{Double-Centered}

With the in-depth research on the theories and practices of foreign language teaching, people come to find that neither the teacher-centered nor the student-centered match of teaching and learning styles can do best to improve the quality of teaching. This is because the teacher-centered relationship construction will inhibit students' initiative, enthusiasm and creativity, etc., while the student-centered relationship construction will decrease the function of the teachers and hence lead to an undesired teaching effect. Therefore, in the late 20th century, the notion of the teacher-student interaction arose, according to which, teaching and learning should be of equal importance. Kolb \& Kolb (2005) introduce the concept of "learning space" in an attempt to elaborate this dynamic nature of the learning style. Chinese scholars (see Xiao, 2005) propose that the teachers and students should be side by side as double centers, or in other words, the dialectical-dynamic double centers. That is, the teachers and students in foreign language teaching should be a dynamic equal match. The notion of dynamic equal match is indeed of epoch-making significance. It takes into account how to mobilize the enthusiasm, initiative and creativity of both the teachers and the students.

\section{A New Measuring Indicator}

Differences occur in the measuring of the match of teaching and learning style in tertiary learners' second language acquisition. Here are the reasons. First, various measuring scales of teaching and learning styles and different hypotheses proposed for different purposes result in the diversity of match measuring indicators. Second, both the teacher-centered and the student-centered style matches measure only the similarities between the teaching styles and the learning styles. However, due to the large number of students in a class, there exists certainly more than one learning style, and the teacher's teaching style is not possibly the same as the students' learning styles. This is to say that the match and mismatch of teaching and learning styles largely coexist. When the students' preferred learning styles are inconsistent with the teacher's teaching style, the mismatch occurs. This will result in students' failure, anger and loss of motivation, etc. (Reid, 1987), and the teachers' tiredness and depression, having no intension to improve their teaching styles. If teachers use a completely different teaching style, they will fail to promote the teaching effectiveness; rather it may be counterproductive (Liu, 2007).

What is then the solution to this problem? Although the impact of the match of teaching and learning style on the learning performance is still controversial, researchers have found in the theoretical exploration and practice that one way to overcome the style mismatch is to introduce a compatible teaching style. This cannot only reflect the leading role of the teacher, but also adapt to different learning styles, and will make the teaching activities accepted by the majority of students (Lu et al., 2009). This method conforms to the research perspective of the teacher-student double center style match, and is in line with the current need of tertiary learners' second language acquisition. To achieve such a scientific teacher-student double center style match, it is necessary to propose an appropriate match measuring indicator, according to which the teaching and learning styles can be adjusted and balanced in time. 
Therefore, for the deficiencies of the existing research of match of teaching and learning styles in tertiary education, this article proposes the match degree of teaching and learning styles as the new indicator from a bidirectional perspective of the teachers and the students. In different second language acquisition processes, the match degree of teaching and learning styles varies. The higher degree the teaching style is realized, the higher degree the learning style will be realized, and vice versa. This indicator makes it unnecessary to consider the similarities between the teaching style and the learning style; it considers to what an extent both the teaching and learning styles are achieved, hence a dynamic match of the teaching and learning styles in second language acquisition.

\section{Achieving Methods}

The teacher-student double centered style match can be achieved from three aspects.

\subsection{Initiate a Student-Centered Teaching Style}

The teachers' teaching style originates from the teaching styles they accepted and their optimal learning methods (Oxford, 1992). It is formed gradually in the long-term teaching practice and needs their constant exploration. Many Chinese foreign language teachers at universities are not consciously aware of their own learning styles and teaching styles. They often teach their students based on their own experience and their styles are still at the stage of their own original teaching style. It is believed that reflection on the teachers' own learning styles would help them appreciate individual needs in learning and differentiate their instruction to accommodate these needs (Hadfied, 2006). In order to help students to form a better learning style and to improve their foreign language performance, a college foreign language teacher should continue his own study by participating kinds of teacher training courses or consulting relevant experts to better understand the outstanding teachers' teaching styles and make comparisons with his own learning and teaching styles. He then needs to consciously develop his studentcentered teaching style, that is, to change from the teacher-centered teaching style to a compatible teaching style to adapt to a variety of students' learning styles. On the other hand, because a better knowledge of learning styles can help the teacher tailor pedagogy so that it best coincides with learning styles exhibited by the majority of students, the teachers should fully understand the students' learning styles in foreign language teaching and accept the fact that different learning styles maybe coexist. Through observation, interview, questionnaires, the teachers can actively explore an appropriate teaching mode to meet the students' requirement and to improve their classroom performance.

\subsection{Developing a Proper Learning Style}

The learning style is formed in the long-term study and practice, and is affected by the surrounding environment, emotion, physiological characteristics and the psychological tendency (Quoted from: Chen \& Cao, 2007). According to Dag \& Gecer (2009), the students who are familiar with their own learning styles will also be able to find their own strengths and weaknesses, and to adjust their learning strategies. In other words, understanding their own learning styles can help them bring their learning potential into play and use various techniques to enhance learning, which in turn may impact the overall educational satisfaction. However, many foreign language teachers at universities pay little attention to the students' learning styles, resulting in the mismatch of the teaching and learning styles. A considerable number of students will lose interest and confidence in foreign language learning, resulting in their poor academic performance (Naimie et al., 2010). Therefore, it is necessary for the teachers to be familiar with the students' learning styles to help them understand their learning styles and guide them to make full use of their learning styles to improve their foreign language learning. They should at the same time help students understand and learn other types of learning styles to be able to adjust their learning styles. The students can thus be able to adapt to different teaching styles to get better language learning achievement.

\subsection{Adjusting the Match of Teaching and Learning Styles}

The classroom activity is a changing interaction between the teacher and the students. Only when the teaching and learning styles adapt to each other is it possible to achieve the desired teaching effect. The new measuring indicator of the match of teaching and learning styles can be helpful for the teachers to understand their own 
teaching styles and for the students to understand their learning styles. Thus, the teachers will be able to adjust their teaching styles to form a compatible teaching style, and the students will be able to understand and expand their own learning styles to give full play to their own learning styles. Forming a dynamic match of teaching and learning styles will improve the quality of foreign language teaching.

\section{References}

Aitkin, M., \& Zuzovsky, R. (1994). Multilevel Interaction Models and Their Use in the Analysis of Large-Scale School Effectiveness Studies. School Effectiveness and School Improvement, 5, 45-73. http://dx.doi.org/10.1080/0924345940050104

Akdemir, O., \& Koszalka, T. A. (2008). Investigating the Relationships among Instructional Strategies and Learning Styles in Online Environments. Computers and Education, 50, 1451-1461. http://dx.doi.org/10.1016/j.compedu.2007.01.004

Arthurs, J. B. (2007). A Juggling Act in the Classroom: Managing Different Learning Styles. Teaching and Learning in Nursing, 2, 2-7. http://dx.doi.org/10.1016/j.teln.2006.10.002

Baker, J. D., \& Cooke, J. E. (1988). Beyond Career Choice: The Role of Learning Style Analysis in Residency Training. Medical Education, 6, 527-532. http://dx.doi.org/10.1111/j.1365-2923.1988.tb00798.x

Beck, C. R. (2001). Matching Teaching Strategies to Learning Style Preferences. The Teacher Educator, 10, 1-15. http://dx.doi.org/10.1080/08878730109555276

Bell, J. (2007). Evaluation of Learning Styles and Instructional Methods in the NROTC Naval Operations and Seamanship Course. Institute for Learning Style Journal, 1, 52-61.

Chen, X., \& Cao, X.-P. (2007). Analysis of the Problems in 12 Learning Style Research. Journal of Jiangxi Normal University (Social Sciences), 6, 129-132.

Coffield, F., Moseley, D., Hall, E., \& Ecclestone, K. (2004). Learning Styles and Pedagogy in Post-16 Learning: A Systematic and Critical Review.

Dag, F., \& Gecer, A. (2009). Relations between Online Learning and Learning Styles. Journal of Procedia Social and Behavioral Sciences, 1, 862-871. http://dx.doi.org/10.1016/j.sbspro.2009.01.155

Ebenezer, J. V., \& Zoller, U. (1993). Grade 10 Students' Perceptions of and Attitudes toward Science Teaching and School Science. Journal of Research in Science Teaching, 30, 175-186. http://dx.doi.org/10.1002/tea.3660300205

Felder, R. M. (1988). How Students Learn: Adapting Teaching Styles to Learning Styles. Proceedings, Frontiers in Education Conference, ASEE/IEEE, Santa Barbara, 489. http://dx.doi.org/10.1109/FIE.1988.35029

Felder, R. M., \& Brent, R. (2005). Understanding Student Differences. Journal of Engineering Education, 1, 57-72. http://dx.doi.org/10.1002/j.2168-9830.2005.tb00829.x

Ford, N., \& Chen, S. Y. (2001). Matching/Mismatching Revisited: An Empirical Study of Learning and Teaching Styles. British Journal of Educational Technology, 1, 5-22. http://dx.doi.org/10.1111/1467-8535.00173

Frank, R., Eleanora, B., \& Melody R. (2009). Learning Styles: A Review of Theory, Application, and Best Practices. American Journal of Pharmaceutical Education, 73, 1-5.

Fullan, M. (1982). The Meaning of Educational Change. New York: Teachers College Press.

Galbraith, V., \& Gardner, R. C. (1988). Individual Difference Correlates of Second-Language Achievement: An Annotated Bibliography. London: University of Western Ontario.

Gardner, H. (1999). Intelligence Reframed: Multiple Intelligences for the 21st Century. New York: Basic Books.

Hadfied, J. (2006). Teacher Education and Trainee Learning Style. Regional Language Centre Journal, 37, 368-386.

Kolb, A. Y., \& Kolb, D. A. (2005). Learning Styles and Learning Spaces: Enhancing Experiential Learning in Higher Education. Academy of Management Learning \& Education, 4, 193-212. http://dx.doi.org/10.5465/AMLE.2005.17268566

Kowoser, E., \& Berman, N. (1996). Comparison of Pediatric Resident and Faculty Learning Styles: Implications for Medical Education. American Journal of the Medical Sciences, 312, 214-218.

http://dx.doi.org/10.1097/00000441-199611000-00004

Liu, Y. G. (2007). The Impact of the Match of Teaching and Learning Styles on the Non-English Majors’ Achievement. Educational Development, 5, 27-30.

Lu, F., Zhang, Y., \& Zhao, X. (2009). Compensatory Effect of "Big Class” Teaching Strategies in Tertiary English Education on the Mismatch of Learning and Teaching Styles. Foreign Languages and Their Teaching, 4, 38-41.

Marshall, C. (1991). Teachers’ Learning Style: How They Affect Student Learning. The Clearing House, 64, 225-227.

Massa, L. J., \& Mayer, R. E. (2006). Testing the ATI Hypothesis: Should Multimedia Instruction Accommodate VerbalizerVisualizer Cognitive Style? Learning and Individual Differences, 16, 321-335. 
http://dx.doi.org/10.1016/j.lindif.2006.10.001

Maxwell, K. L., McWilliam, R. A., Hemmeter, M. L., Ault, M. J., \& Schuster, J. W. (2001). Predictors of Developmentally Appropriate Classroom Practices in Kindergarten through Third Grade. Early Childhood Research Quarterly, 16, $431-452$. http://dx.doi.org/10.1016/S0885-2006(01)00118-1

Naimie, Z., Siraj, S., Piaw, C. Y., Shagholi, R., \& Abuzaid, R. A. (2010). Do You Think Your Match Is Made in Heaven? Teaching Styles/Learning Styles Match and Mismatch Revisited. Procedia-Social and Behavioral Sciences, 2, 349-353. http://dx.doi.org/10.1016/j.sbspro.2010.03.023

Oxford, R., \& Ehrman, M. E. (1993). Second Language Research on Individual Differences. In W. Grabe (Ed.), Annual Review of Applied Linguistics (pp. 188-205). Cambridge: Cambridge University Press.

Oxford, R. (1989). The Role of Styles and Strategies: A Synthesis of Studies with Implications for Strategy Training. System, 17, 235-247. http://dx.doi.org/10.1016/0346-251X(89)90036-5

Oxford, R. L., Hollaway, M. E., \& Horton-Murillo, D. (1992). Language Learning Styles: Research and Practical Considerations for Teaching in the Multicultural Tertiary ESL/EFL Classroom. System, 20, 439-456.

http://dx.doi.org/10.1016/0346-251X(92)90057-A

Peng, L. (2002). Applying Learning Style in Instructional Strategies. Center for Development of Teaching and Learning, 5, $1-3$.

Reid, J. (1996). The Learning-Centered Classroom. TESOL Matters.

Reid, J. M. (1987). The Learning Style Preferences of ESL Students. TESOL Quarterly, 21, 87-111. http://dx.doi.org/10.2307/3586356

Rogers, K. M. A. (2009). A Preliminary Investigation and Analysis of Student Learning Styles Preferences in Further and Higher Education. Journal of Further and Higher Education, 33, 13-21. http://dx.doi.org/10.1080/03098770802638234

Saracho, O. N. (1990). The Match and Mismatch of Teachers and Students' Cognitive Styles. Early Child Development and Care, 54, 99-109. http://dx.doi.org/10.1080/0300443900540107

Shaugnessy, M. F. (1998). An Interview with Rita Dunn about Learning Styles. The Clearing House, 71, 141-145. http://dx.doi.org/10.1080/00098659809599346

Shuell, T. J. (1996). Teaching and Learning in a Classroom Context. In D. C. Berliner, \& R. C. Calfee (Eds.), Handbook of Educational Psychology (pp. 726-764). New York: Macmilan.

Skehan, P. (1989). Individual Indifferences in Second Language Learning. London: Edward Arnold.

Tulbure, C. (2011). Do Different Learning Styles Require Differentiated Teaching Strategies? Procedia-Social and Behavioral Sciences, 11, 155-159. http://dx.doi.org/10.1016/j.sbspro.2011.01.052

Wentura, D. F. (1985). The Effects of Matching Teaching Styles and Learning Styles on Student Performance in University Classes. Dissertation Abstracts International, 46, 605.

Xiao, L. Q. (2005). Reflections on the Macro Mode of China’s English Teaching. Foreign Language Education, 5, 35-42.

Zhang, L. F. (2006). Does Student-Teacher Thinking Style Match/Mismatch Matter in Students’ Achievement? Educational Psychology, 26, 395-409. http://dx.doi.org/10.1080/01443410500341262 